\title{
Clindamycin resistance among Staphylococcus aureus causing skin and ear infections from Chennai, South India
}

\author{
Betsy S Dass ${ }^{1 *}$, A Nagarajan $^{1}$, Padma Krishnan ${ }^{1}$, G Sivakumar $^{2}$ \\ From First International Science Symposium on HIV and Infectious Diseases (HIV SCIENCE 2012) \\ Chennai, India. 20-22 January 2012
}

\section{Background}

Antibiotic resistance in S. aureus is one of the major concerns and the rate of MRSA has dramatically increased in recent years. Clindamycin belongs to the MLS group and is used to treat skin and soft tissue infections. Resistance to clindamycin may be inducible (iMLSB) or constitutive (cMLSB) and it is present both in MRSA and MSSA. Treatment failure has been reported both in iMLSB and cMLSB cases. Knowledge on clindamycin resistance is important for its proper use. Hence, the present study was done to detect clindamycin resistance among $S$. aureus causing skin and ear infections.

\section{Methods}

84 samples (skin - 55, ear discharge - 29) were collected from the OPD and wards of tertiary hospital in Chennai. Isolation and identification of $S$. aureus was done according to standard protocol. Antibiotic susceptibility pattern was tested for all isolates to various antibiotics. MRSA screening was done by cefoxitin disc diffusion method. Erythromycin induced clindamycin resistance was detected by using D-test. MIC was determined by agar dilution method.

\section{Results}

From the 84 clinical samples, $49 \mathrm{~S}$. aureus isolates were obtained of which 32 (65\%) were MRSA. 32 (65\%) strains were resistant to erythromycin and $3(6.1 \%)$ showed resistance to clindamycin with MIC of $256 \mu \mathrm{g} / \mathrm{ml}$. Of the 32 erythromycin resistant $S$. aureus isolates, 18 exhibited

\footnotetext{
* Correspondence: betsysdass@gmail.com

'Dept. of Microbiology, Dr. ALM PGIBMS, University of Madras, Chennai, India Full list of author information is available at the end of the article
}

inducible clindamycin resistance. All clindamycin resistant isolates were found to be MRSA.

\section{Conclusion}

Increasing resistance to clindamycin has been found among MRSA indicating urgent need for guidelines on its proper use to decrease the morbidity and mortality by MRSA infections.

\section{Author details}

'Dept. of Microbiology, Dr. ALM PGIBMS, University of Madras, Chennai, India. 'Dept. of General Surgery, Rajiv Gandhi Govt. General Hospital, Chennai, India.

Published: 4 May 2012

\section{doi:10.1186/1471-2334-12-S1-P70 \\ Cite this article as: Dass et al: Clindamycin resistance among \\ Staphylococcus aureus causing skin and ear infections from Chennai, \\ South India. BMC Infectious Diseases 2012 12(Suppl 1):P70.}

Submit your next manuscript to BioMed Central and take full advantage of:

- Convenient online submission

- Thorough peer review

- No space constraints or color figure charges

- Immediate publication on acceptance

- Inclusion in PubMed, CAS, Scopus and Google Scholar

- Research which is freely available for redistribution Submit your manuscript at
www.biomedcentral.com/submit C Biomed Central 